\title{
Tectonic control of tufa occurrences in the Podhale Synclinorium (Central Western Carpathians, southern Poland)
}

\author{
Leonard MASTELLA and Barbara RYBAK-OSTROWSKA
}

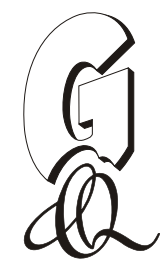

\begin{abstract}
Mastella L. and Rybak-Ostrowska B. (2012) - Tectonic control of tufa occurrences in the Podhale Synclinorium (Central Western Carpathians, southern Poland). Geol. Quart., 56 (4): 733-744, doi: 10.7306/gq.1065

Tufas in the Podhale Synclinorium (southern Poland) occur as encrustations on moss and plant remains, crusts, porous, clastic and massive tufas. The tufas are almost entirely composed of calcite with small admixture of quartz, illite and chlorite. These deposits indicate the biotic and/or abiotic origin of calcium carbonate. The tufas occur in the vicinity of map-scale and minor fault zones. They precipitate near fissure springs linked with small faults and fault rocks or seepages along them. Exposures with tufas occur along several oblique and lateral zones. The oblique zones are related to Białka and Biały Dunajec faults that have normal components. The lateral zones of tufa occurrences are connected with lateral faults limiting the "zone of beds with gentle dips" and extensional brittle structures within the hinge of the synclinorium. The relationship of the tufa with brittle extensional structures suggests Quaternary tectonic activity of the Podhale Synclinorium that can be explained by continued uplift in the area studied.
\end{abstract}

Leonard Mastella and Barbara Rybak-Ostrowska, Faculty of Geology, University of Warsaw, wirki i Wigury 93, 02-089 Warszawa, Poland, e-mails: lmastella@uw.edu.pl, barbara.rybak@uw.edu.pl (received: August 17,2012; accepted: November 7, 2012; first published online: December 19, 2012).

Key words: tufas, fault zones, active tectonics, Podhale Synclinorium, Central Western Carpathians.

\section{INTRODUCTION}

The occurrence of calcareous tufas in the Polish part of the Podhale Synclinorium has long been documented (Halicki, 1930; Halicki and Lilpop, 1932). Several occurrances of these rocks in the Podhale area have been subsequently described (Birkenmajer, 1958a, 1964; Małecka, 1974; Mastella, 1975; Watycha, 1976, 1977; Mastella and Mizerski, 1977; Szulc, 1983; Pazdur, 1987; Mastella et al., 1996; Alexandrowicz, 1997); additionally, 80 tufa and travertine sites have been listed from the Slovak part of the Central Carpathian Paleogene Basin of the Central Western Carpathians (Leško, 1958; Zýka and Vtělenský, 1960; Ložek, 1961, 1964; Fusán, 1963; Kovanda, 1971; Gross and Köhler, 1980; Čabalová, 1991; Gradziński et al., 2008a). Tufas have also been documented in the Tatra Mts. area (Rabowski, 1930; Gradziński et al., 2001; Smieja and Smieja-Król, 2007) and in the Pieniny Klippen Belt (Alexandrowicz, 2004 and references therein).

Sites of tufas in the Podhale Synclinorium have been observed in areas of flowing water: (a) in the upper parts of minor streams, which are difficult to access; (b) on steep banks of short tributaries of main rivers and streams; (c) on river terraces and their slopes. Furthermore, tufa deposits are usually covered with moss and grass. Therefore, most of the tufa sites have remained unnoticed till present. Detailed field studies focused on documenting the occurrence of tufas adjacent to fault zones, have allowed us to recognize 71 tufa sites in the Podhale Synclinorium (Appendix 1 - supplementary file ${ }^{*}$ ). Study of the tufas is ongoing. This paper describes the distribution and fabric of tufa deposits and indicates their relationships with the tectonics of the Podhale Synclinorium.

\section{GEOLOGICAL SETTING}

The Podhale Synclinorium (Mastella, 1975) is composed of rocks that form part of the Paleogene cover of the Central Western Carpathians (Figs. 1 and 2; Marschalko, 1968; Ksią kiewicz, 1972). The Podhale Synclinorium comprises shales and sandstones of Oligocene to Early Miocene age (Gedl, 2000a, b; Garecka, 2005), lying on deposits of the 


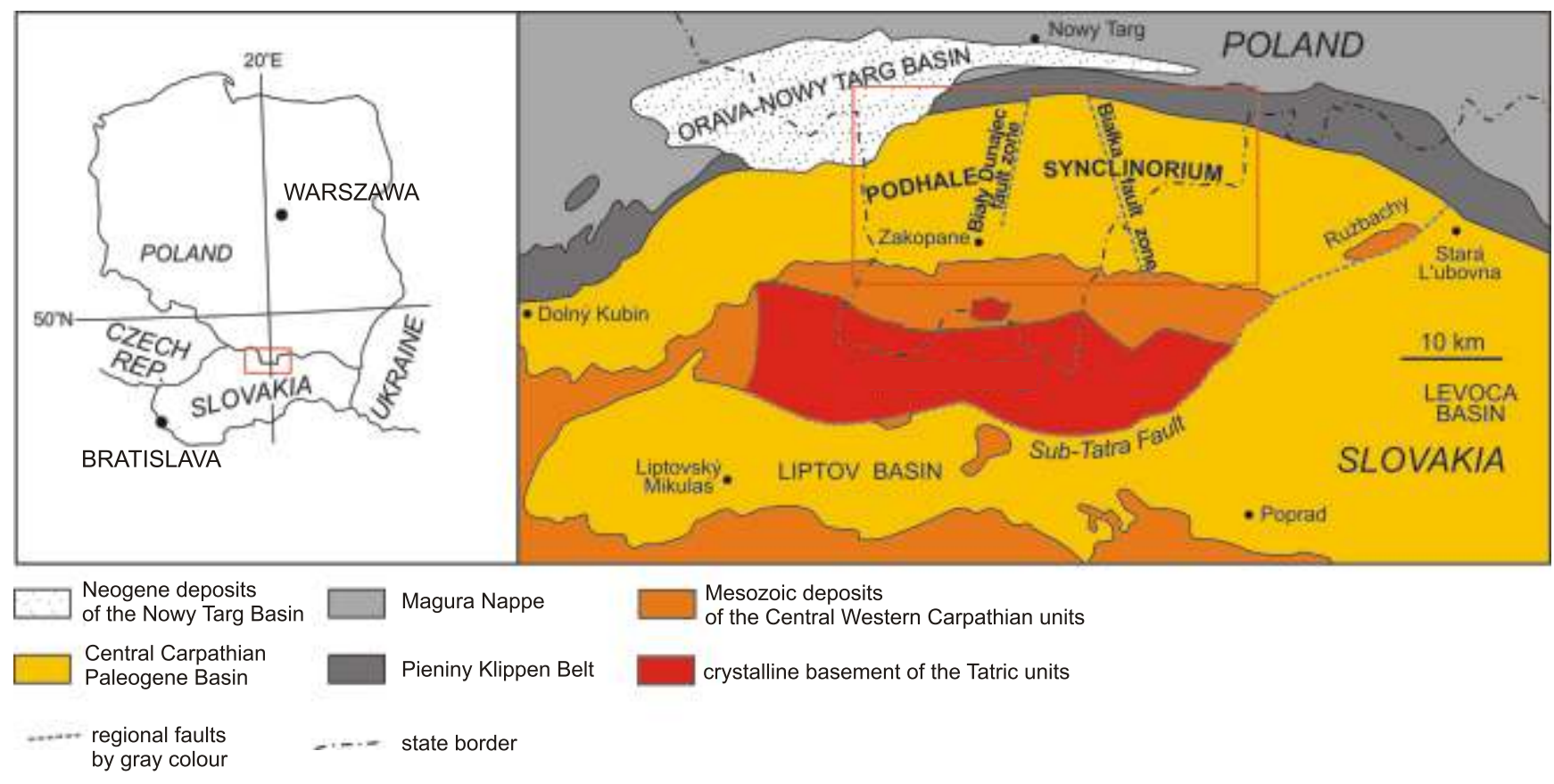

Fig. 1. Geological sketch-map of the northern part of the Central Western Carpathians with location of the study area (after ytko et al., 1989 and Biely et al., 1996, modified)

"Nummulitic Eocene" (Sokołowski, 1959; Watycha, 1968) that represent the Borové Formation (sensu Gross et al., 1984; Fig. 3). The thickness of the entire succession is estimated at 2.5-4 km (Gołąb, 1959; Watycha, 1959, 1976, 1977; Mastella, 1975).

The sedimentary sequence in the Podhale Synclinorium comprises four informal lithostratigraphic units: the Szaflary Beds in the lowermost part of the succession in the northern limb of the synclinorium, followed by the Zakopane, Chochołów and Ostrysz Beds in the upper part of the succession across the entire synclinorium area (Gołąb, 1959; Watycha, 1959, 1968; Dudziak, 1983, 1986). The beds correlate with the Śambron Member and the Huty, Zuberec and Biely Potok formations, respectively, in the Slovak part of the Central Carpathian Paleogene (Gross et al., 1984). Lithostratigraphic boundaries between the beds are variously shown on maps by different authors (Birkenmajer, 1968; Watycha, 1974, 1976; Małecka, 1982).

The contact of the Podhale Synclinorium with the Sub-Tatric units is sedimentary, whereas that with the Pieniny Klippen Belt is tectonic (Uhlig, 1897, 1903; Birkenmajer, 1958b; Figs. 1-3). Bedding dips are steep near the Pieniny Klippen Belt and become more gentle towards the south. Dip values significantly increase again in the zone of the periPieniny flexure. Further to the south occurs an uplifted "zone of beds with gentle dips" (Mastella, 1975), followed by an axial zone (Fig. 2) with mesofolds. The southern limb of the synclinorium is monoclinal with a narrow belt of tectonic deformation near the Sub-Tatric units (Fig. 2). These parallel tectonic zones are cut by large transverse fault zones (Mastella, 1975; Mastella et al., 1996). Two of them, the Białka and Biały Dunajec fault zones cut the Pieniny Klippen Belt to the north and continue in the Sub-Tatric Units to the south (Fig. 2). These are scissor faults and they uplift the southern part of the Podhale Synclinorium and lower the area between the Białka and Biały Dunajec rivers in the northern part of the synclinorium (Mastella, 1975; Mastella et al., 2012).

The structure of the Podhale Synclinorium began to form as a result of horizontal $\mathrm{N}-\mathrm{S}$ compression and its final configuration is the consequence of uplift of the area (Mastella, 1975; Buday et al., 1967). Mastella (1975) and Ludwiniak (2010) considered the Late Oligocene/Miocene as the beginning of the formation of the Podhale Synclinorium. The same age of N-S compression in the Central Western Carpathians is indicated by Fodor et al. (1999), although these authors do not exclude that the compressional regime might have operated as late as the Middle Miocene. Similar suggestions were made by Vojtko et al. (2010) based on data from palaeostress analysis in the Špiska Magura Mts. The uplift of the Podhale Synclinorium commenced from the Middle Miocene times and continues at present (Makowska and Jaroszewski, 1987; Anczkiewicz et al., 2005; Perski, 2008; Śmigielski et al., 2012).

\section{METHODS}

Fieldwork was carried out across the entire Podhale area using topographic maps at the scale of 1:10 000. Some 71 locations with calcareous tufas (Appendix 1) have been documented since the 1960s, based on our observations as well as archival data of the Laboratory of Tectonics and Geological Mapping, Institute of Geology, University of Warsaw (Kędzierska, 2001; Majewska, 2001; Dziudzik, 2002; Stępczak, 2011). Most of the tufas were localized by pacing and marked on the topographic maps. The locations were converted to geographic coordinates by geoportal. Some of the tufas have been previously reported, but most are documented for the first time. The number of tufa sites is variable due to erosion of the existing exposures and creation of new ones. Observations were carried out along rivers and streams as well as along their tributaries. The locations of many tufas coincide with map-scale faults and fault zones 


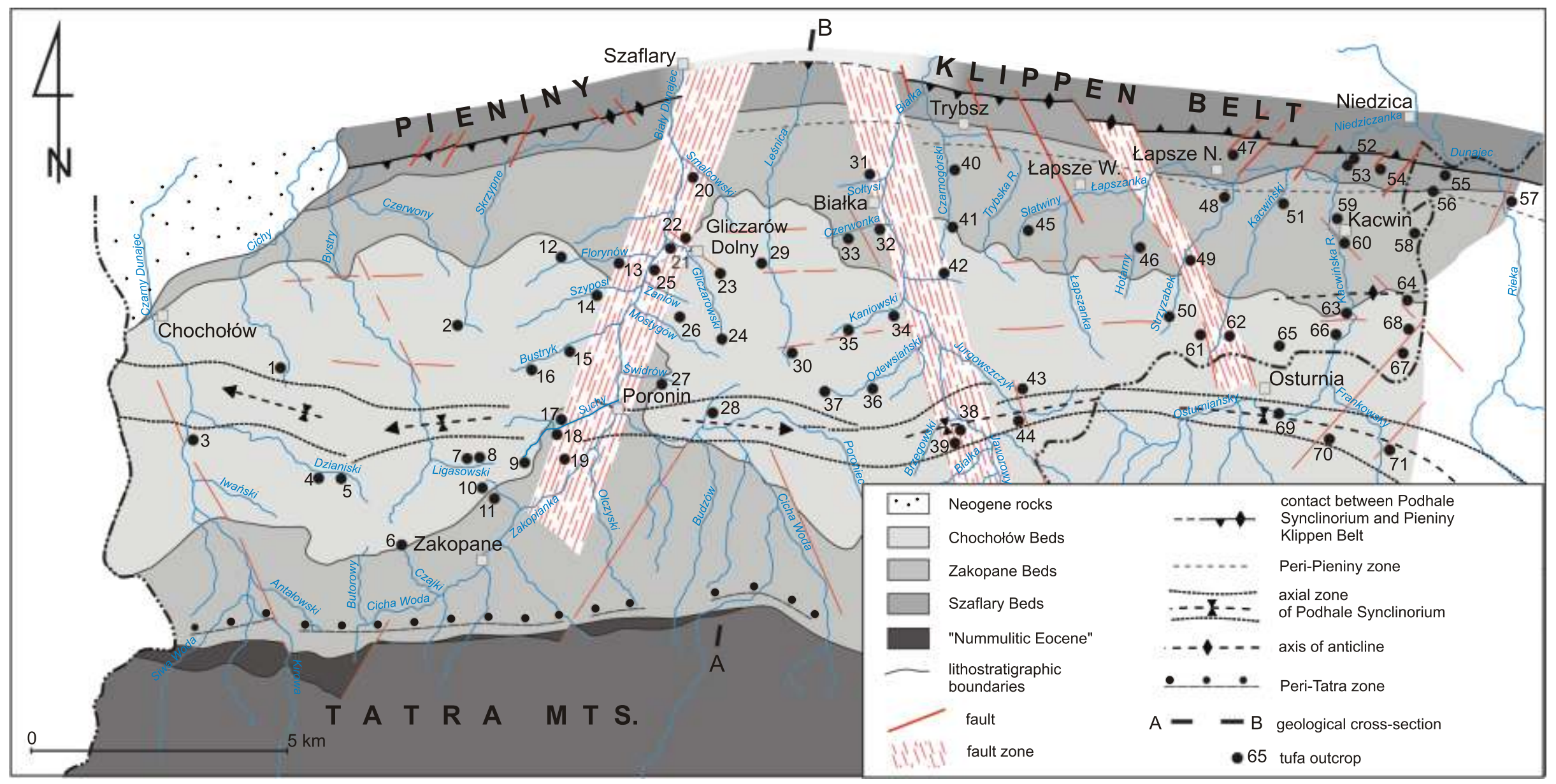

Fig. 2. Location of tufa outcrops on a geological sketch-map of the Podhale area (compiled after Watycha, 1974, 1976; Mastella, 1975; Bac-Moszaszwili et al., 1979; Małecka, 1982) 


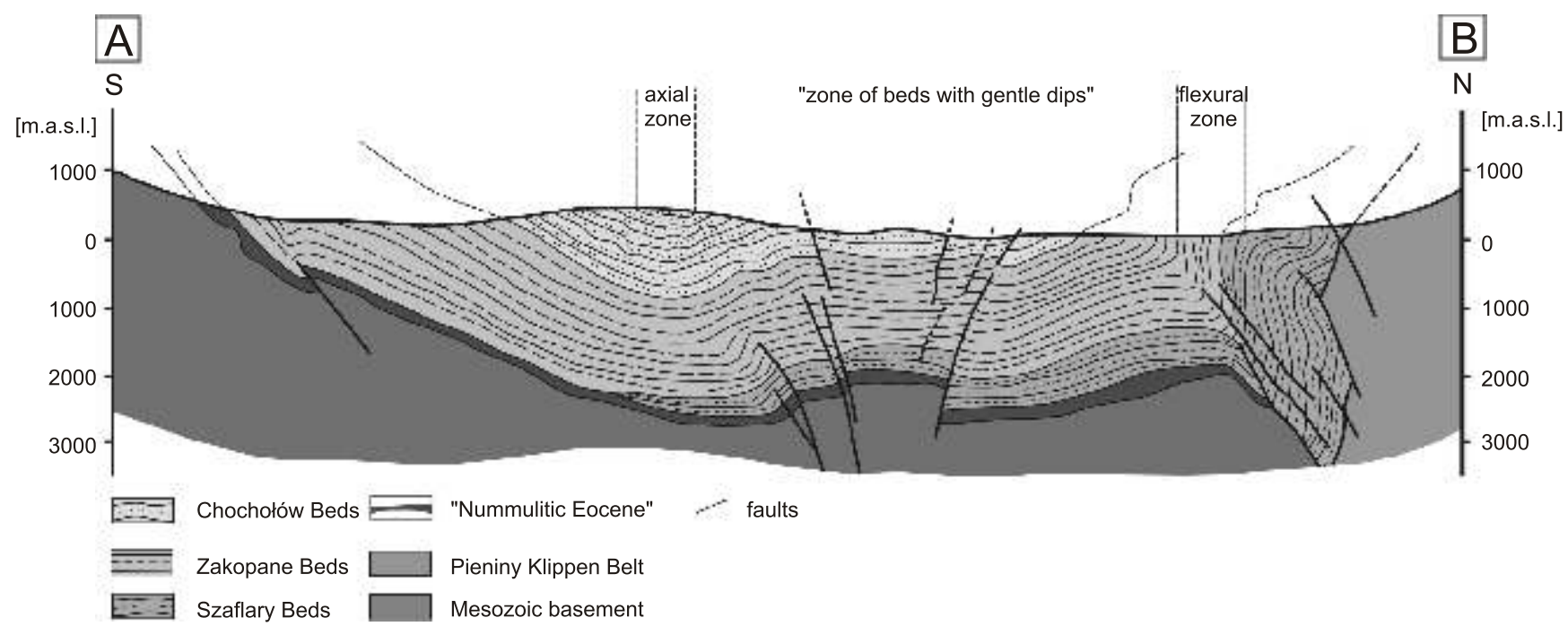

Fig. 3. Schematic geological cross-section through the Podhale Synclinorium

(Fig. 2) as well as mesofaults (Figs. 4-6). The tufas were sampled for thin section preparation and geochemical analyses. The mineralogical composition of the tufas was determined with a DRON-1 diffractometer in the Institute of Geochemistry, Mineralogy and Petrology, University of Warsaw. Petrographic observations were performed on selected samples of tufa using a polarized microscope at the Institute of Geology, University of Warsaw and scanning electron microscope in the Institute of Geological Sciences, Polish Academy of Sciences in Warsaw.

\section{TERMINOLOGY}

Freshwater carbonate terminology has developed over the decades. Many studies describing the etymology and origin of the terms travertine and tufa, used widely in the literature, are listed by Pentecost (2005). The lithology of the deposits studied, their textures, the presence of plant and their imprints allow us to use the term calcareous tufa (Szulc, 1983; Pedley, 1990; Gradziński, 2010) or meteogene travertine (sensu Pentecost, 1995) for most of their occurrences. Tufas have their carbon dioxide source in shallow circulation waters (Chafetz and Folk, 1984). The linkage of the deposits studied with fault zones, the morphological forms of some of them (e.g., mounds) and isotope data (Pazdur et al., 1988) suggest that these deposits may derived carbon dioxide from deep circulation waters and thus can be regarded as travertine (Chafetz and Folk, 1984; Pedley, 1990) or thermogene travertine (Pentecost, 1995). However, the final assignment of the deposits studied as travertines depends on stable isotope analysis. Thus, we consequently use herein the term calcareous tufa for all the types of freshwater carbonate deposits in this region.

\section{MACROSCOPIC OBSERVATIONS}

Several independent classifications of freshwater carbonates based on different criteria have been proposed (Julia, 1983; Szulc, 1983; Chafetz and Folk, 1984; Rutkowski, 1991; Pentecost and Viles, 1994; Ford and Pedley, 1996). During fieldwork, we have used the classification based on macroscopic textural and morphological criteria proposed by Gruszczyński and Mastella (1986).

Several textural varieties of tufas were distinguished during the studies. The most common are thin coatings (Fig. 2 - e.g., 7 , 34,62 ), up to several mm thick, forming crusts on plant remains and tree roots on slopes of stream terraces and on pebbles and surfaces on stream bottoms (Figs. 4 and 7A, J, K). Crusts occur in areas of low flow or seeping water and occur in a variety of forms ranging from smooth covers, through nodular forms to aggregates of small calcite crystals (Figs. 4 and 7K). Frequently, the irregular crust surfaces develop in areas of plant growth and over deposit-cemented plant debris. Crusts cover areas ranging in size from a few to tens of square metres. These forms have been observed in almost all tufa outcrops in the study area.

A special form of tufa is represented by fragile calcareous encrustations on moss (Fig. 2 - e.g., 22, 52, 32) occurring on slopes of main stream valleys or their tributaries in areas of low flow or seeping water. These may form calcified moss curtains in shaded overhangs (Figs. 5 and 7) of up to few metres in high and several metres in width. Beneath the moss curtains, in cave-like niches, there occur characteristic speleothem forms of variable shape.

Tufas with a highly porous texture, frequently hard but locally soft and poorly lithified (Fig. 2 - e.g., 22, 33, 34) occur on the stream bottoms (Fig. 8), on stream terraces as well as in the seepage zones of stream terrace slopes (Fig. 7). They can cover an area of up to several square metres and may exceed a few metres in thickness. Porous tufas frequently show a laminated fabric and occasionally a texture typical of stromatolites.

Clastic tufas, porous, hard (Fig. 2 - e.g., 6, 22, 36, 37) cementing alluvial gravel, fragments of local rock, breccia, oncoids, peloids or older tufa clasts (Fig. 7F) form on stream valley slopes (Fig. 6). Their thickness varies and may exceed several metres. Occasionally, blocks of clastic tufas detached and displaced downwards, were found in the stream bottoms.

Massive tufas, hard, locally thinly bedded, frequently with a laminated fabric (Fig. 2 - e.g., 18, 22, 33) form on terraces and terrace slopes as well as on stream valley slopes (Fig. 5). 


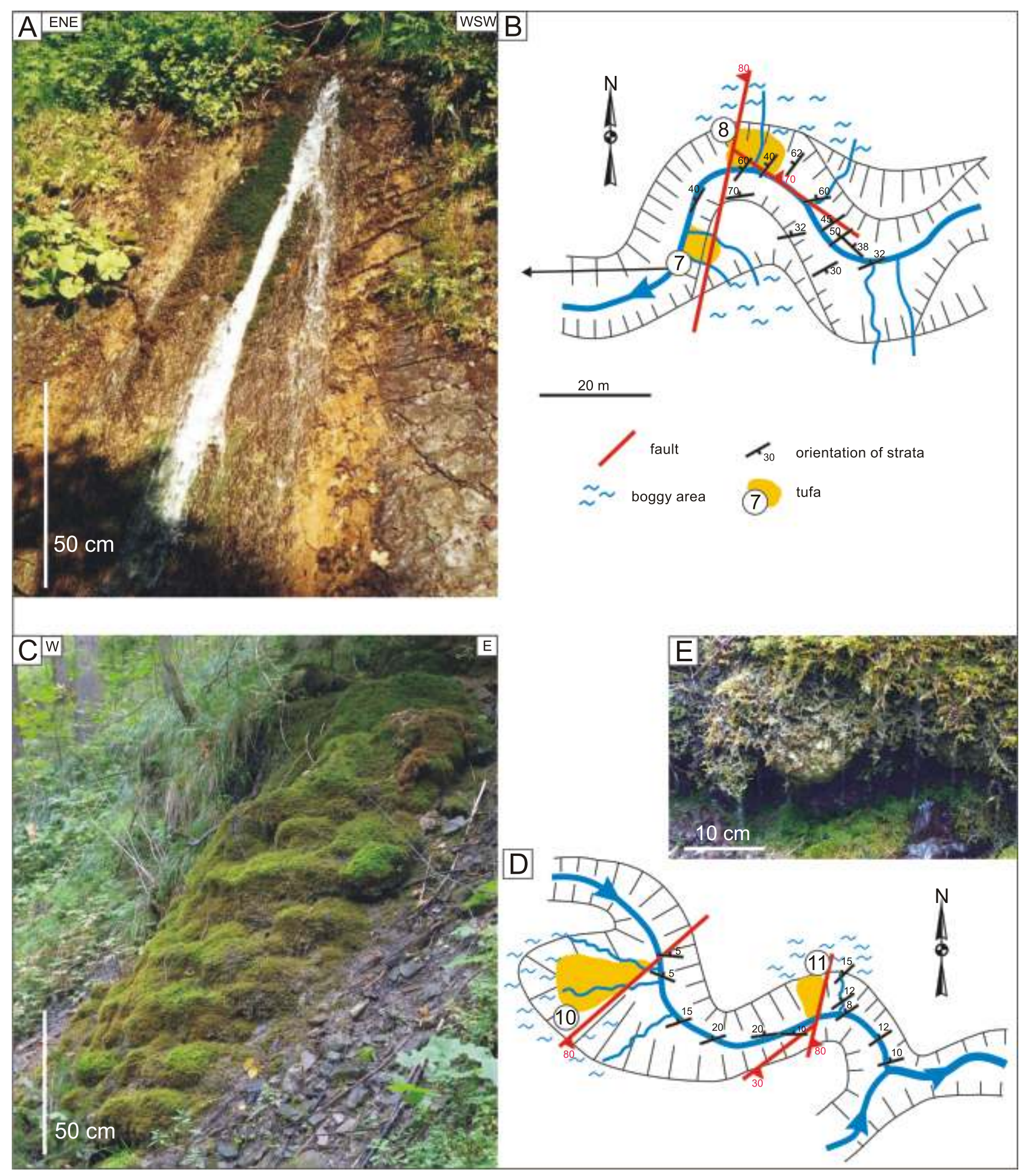

Fig. 4. Tufas

A - active crusts (yellow) (no. 7) in the Ligasowski Stream; B - sketch of outcrops no. 7 and 8 (after Dziudzik, 2002, modified); C - active calcareous tufa covered by moss (no. 11) in the Kotelnica Stream; D - sketch of outcrops no. 10 and 11 (after Dziudzik, 2002, modified); explanations and scale as in B; $\mathbf{E}$ - speleothems in shaded niche beneath encrusted moss (no. 11) 


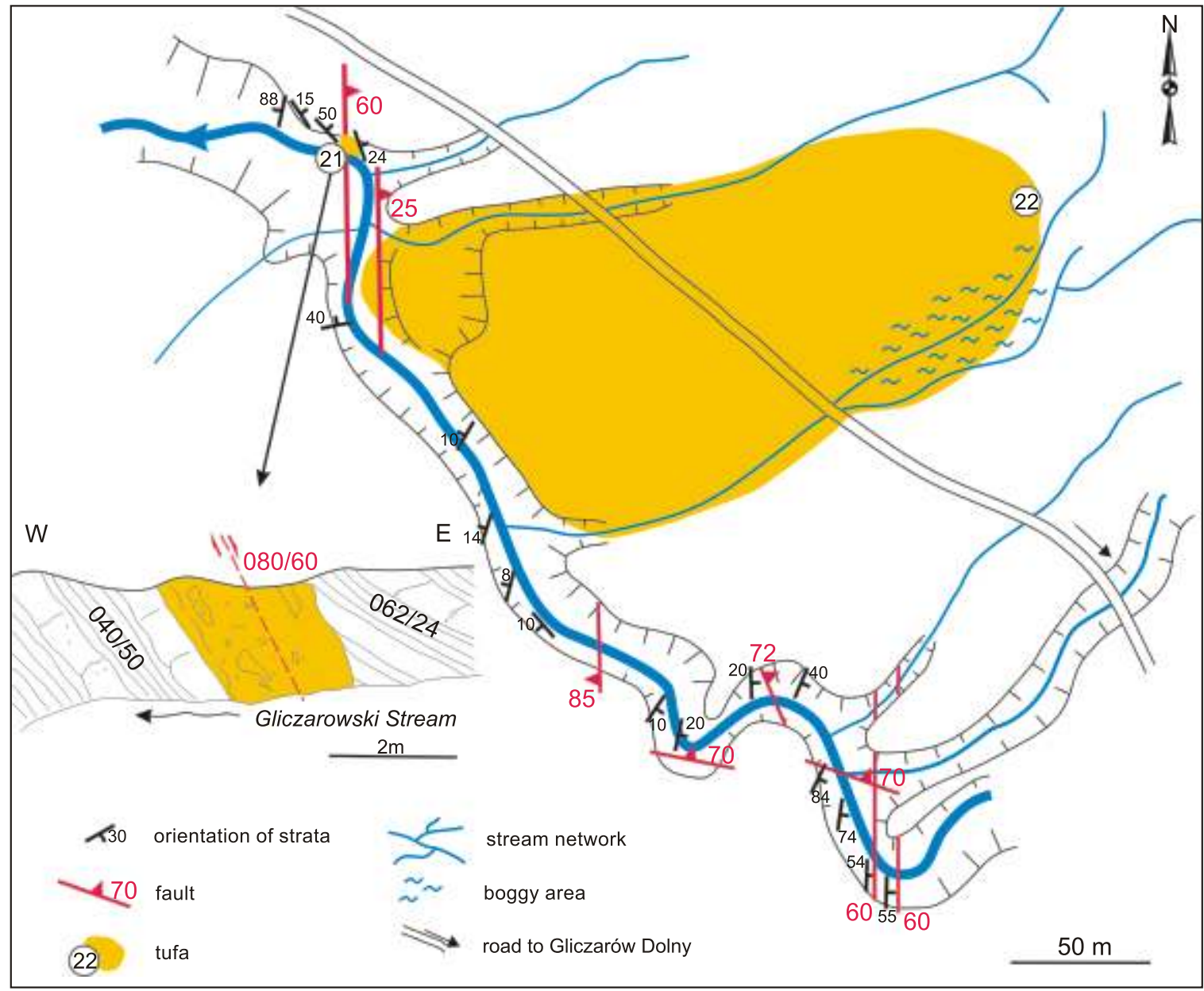

Fig. 5. Sketch of the calcareous tufa occurrence in the Gliczarowski Stream and its vicinity (no. 22) with schematic geological cross-section of outcrop no. 21 (after Majewska, 2001, modified)

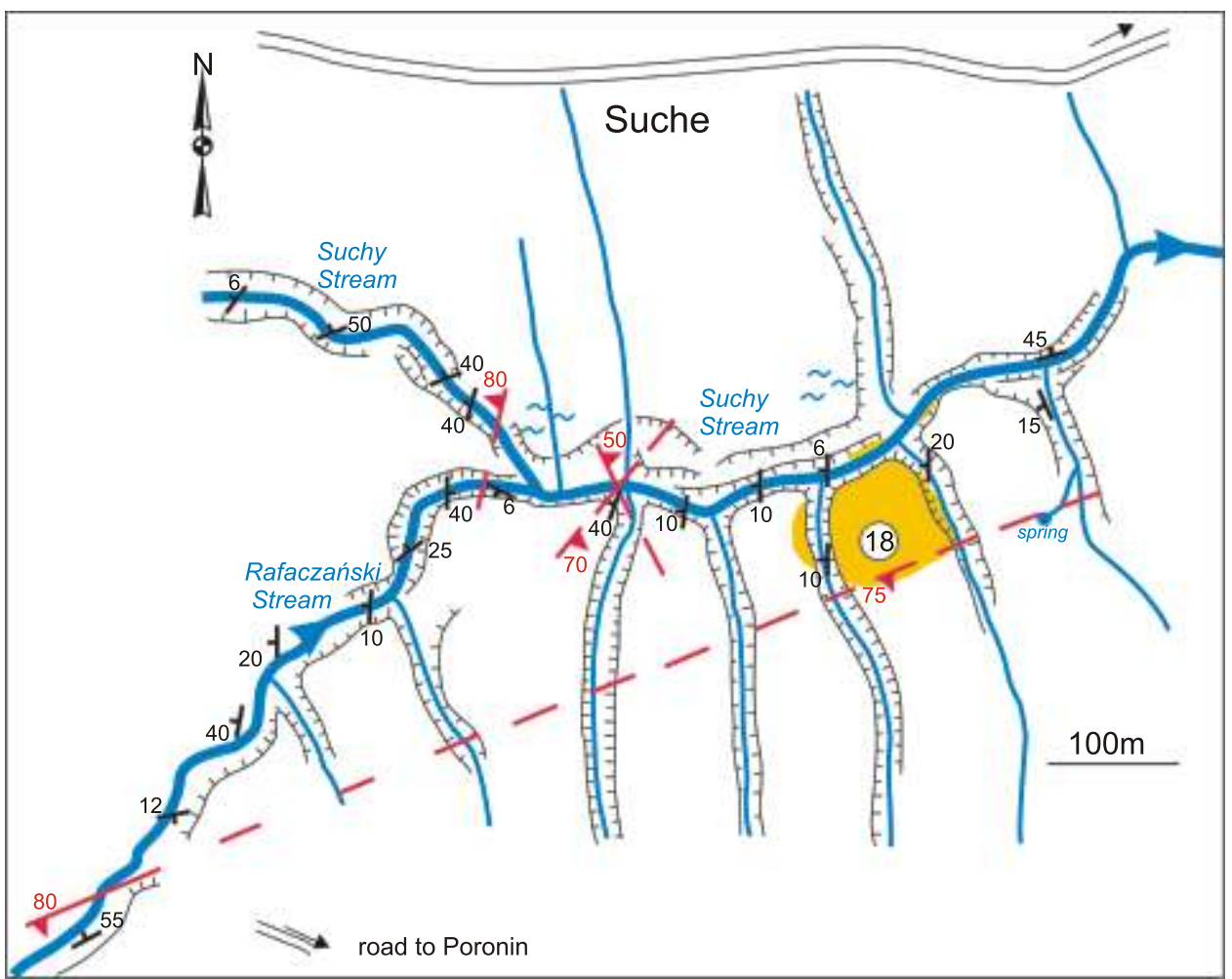

Fig. 6. Sketch of the calcareous tufa occurrence in the Suchy Stream and its vicinity (no. 18) 


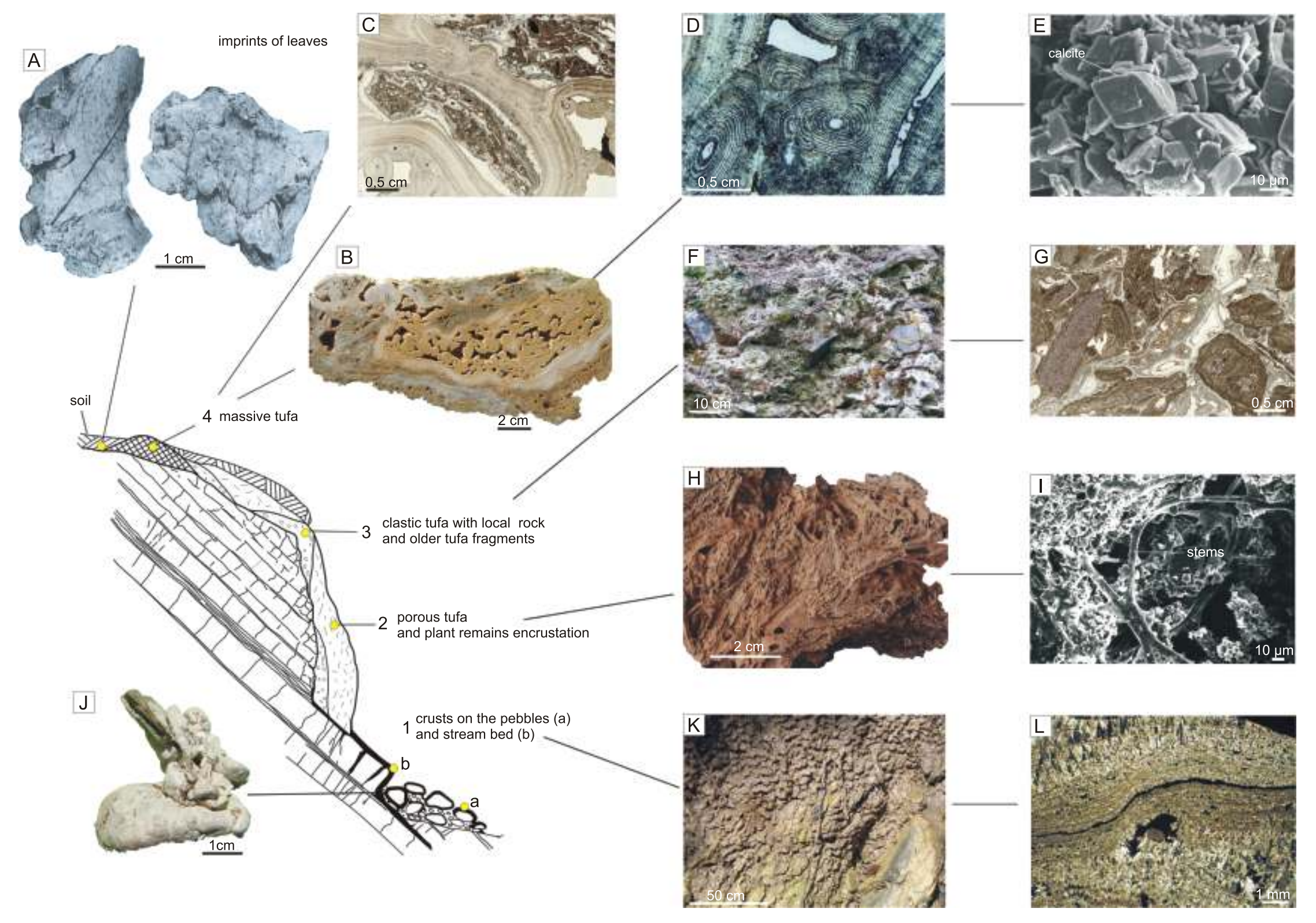

Fig. 7. Textural types of tufas on the basis of morphological scheme of tufa deposits (after Gruszczyński and Mastella, 1986, modified)

A - Ligasowski Stream (no. 8); B, D, E - Suchy Stream (no. 17); C - Czarnogórski Stream (no. 40); F - Suchy Stream (no. 18; fot. M. Ludwiniak); G - Osturniański Stream (no. 69); H, I - Czerwonka Stream (no. 33); J - Gliczarowski Stream (no. 22); K, L - Niedziczanka Stream (no. 53) 


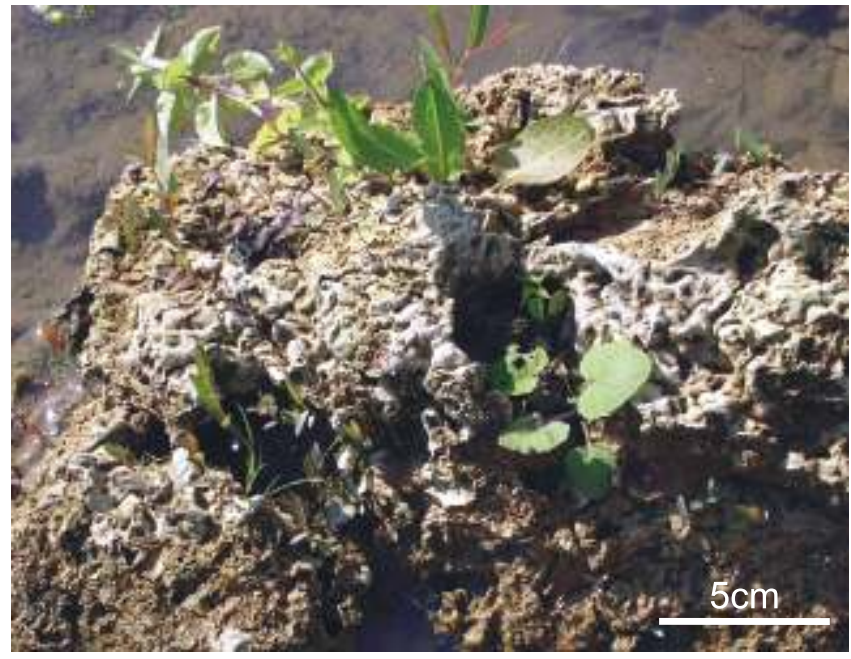

Fig. 8. Active porous tufa colonised by plants, the bedrock of the Niedziczanka Stream, outcrop no. 53

Their thickness varies between particular outcrops and may exceed several metres.

Massive, clastic and porous tufas (Fig. 7) build bodies of different size and geometry, from tabular or fan-like shapes through cascades to mounds (Figs. 4 and 5). The spatial distribution of different tufas is heterogeneous with a complex internal arrangement (cf. Alexandrowicz, 1997). They may continue into crusts and plant encrustations at their margins that locally spread into the stream bed.

Tufas often occur on the outer washed-over stream banks and in the inner reaches of streams in areas of small tributaries. They precipitate near fissure springs linked with small faults and breccia zones or seepages occurring in their prolongations. The relationships of tufas to faults have been observed in individual exposures as well as in series of exposures located along map-scale faults. An example is the occurrence of tufas along lateral faults limiting a "zone of beds with gentle dips" (Figs. 2 and 3), particularly evident in the southern part of the Kaniowski Stream (Fig. 2; outcrops no. 34, 35) to the east in the region of Kacwin (Fig. 2 - no. 63, 66, 68). Another example is the well-known exposure of tufas in the region of Gliczarów (Halicki, 1930), where a map-scale fault contacts the Biały
Dunajec fault zone (Fig. 2, no. 22; Mastella, 2001; Mastella et al., 2012). The tufa crop outs within bogs on the northern flat part of the Gliczarowski Stream valley (Fig. 5). It occupies an area of about 6 hectares in a fan-like form.

A unique occurrence of tufa has been noted on the southern slope of the Suchy Stream valley (Fig. 2, no. 18). A series of tufa mounds, exceeding several metres in height and diameter, occupy a field of about 1 hectare between two minor tributaries of the Suchy Stream (Fig. 6). It is the largest occurrence of deposits in such a morphological form in the Podhale Synclinorium.

\section{COMPOSITION AND FABRIC OF THE TUFAS}

X-ray diffraction study shows that the tufa consists mainly of calcium carbonate with a small admixture of quartz, illite and chlorite (Fig. 9). It is consistent with XRD data from the Slovak part of the Paleogene sedimentary cover (Zýka and Vtělenský, 1960; Čabalová, 1991). The calcium carbonate content is about $95 \%$ in most samples. Thus most tufas are white in colour with various shades of grey; occasionally, they are also yellow or brown.

The tufas display varied macro- and microscopic porosity, sub-divided after Choquette and Pray (1970) into intergranular, mouldic, shelter and framework porosity. Intergranular porosity has been observed in clastic tufas (Fig. 7F, G). This has been observed in clasts of local rock as well as in older tufas (Fig. 7G). Mouldic porosity commonly occurs in tufas that cement plant fragments and tree roots (Fig. 7C, D). It is also frequent in clastic tufas (Fig. 7G). Shelter porosity has been found beneath leaf surfaces and other flat plant fragments. Moss cementation by calcium carbonate produces tufas with high framework porosity (Fig. 7H, I). These tufas often have a porous and fragile texture.

Microscopic observations show that the tufas consist of two polymorphs of crystalline calcium carbonate: dominant calcite (Fig. 7E) and rare aragonite. Primary calcite crystals are frequently fine anhedral, only occasionally coarse euhedral. Small voids and hollows in tufas with porous framework contain sub-euhedral calcite crystals. Aragonite is represented by small crystals randomly distributed within the porous tufas or by small clusters of crystals.

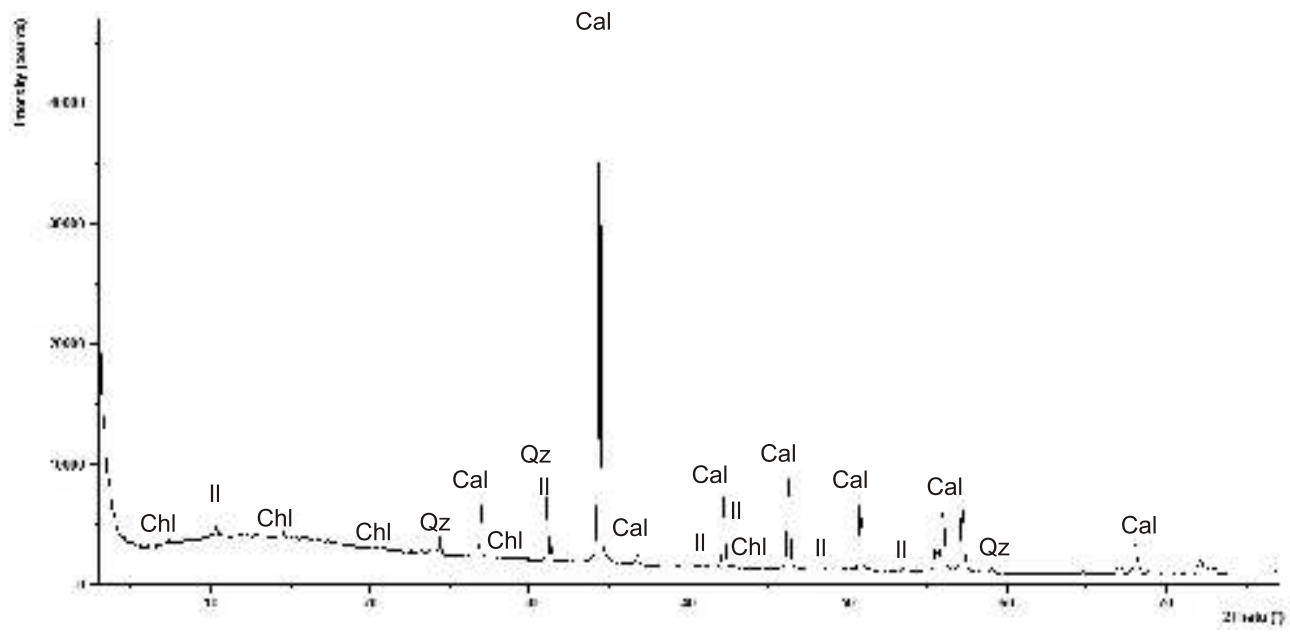

Fig. 9. Example of X-ray diffraction identification of mineralogical composition of tufas

Cal - calcite, Il - illite, Chl - chlorite, Qz - quartz; Czarnogórski Stream (outcrop no. 40) 


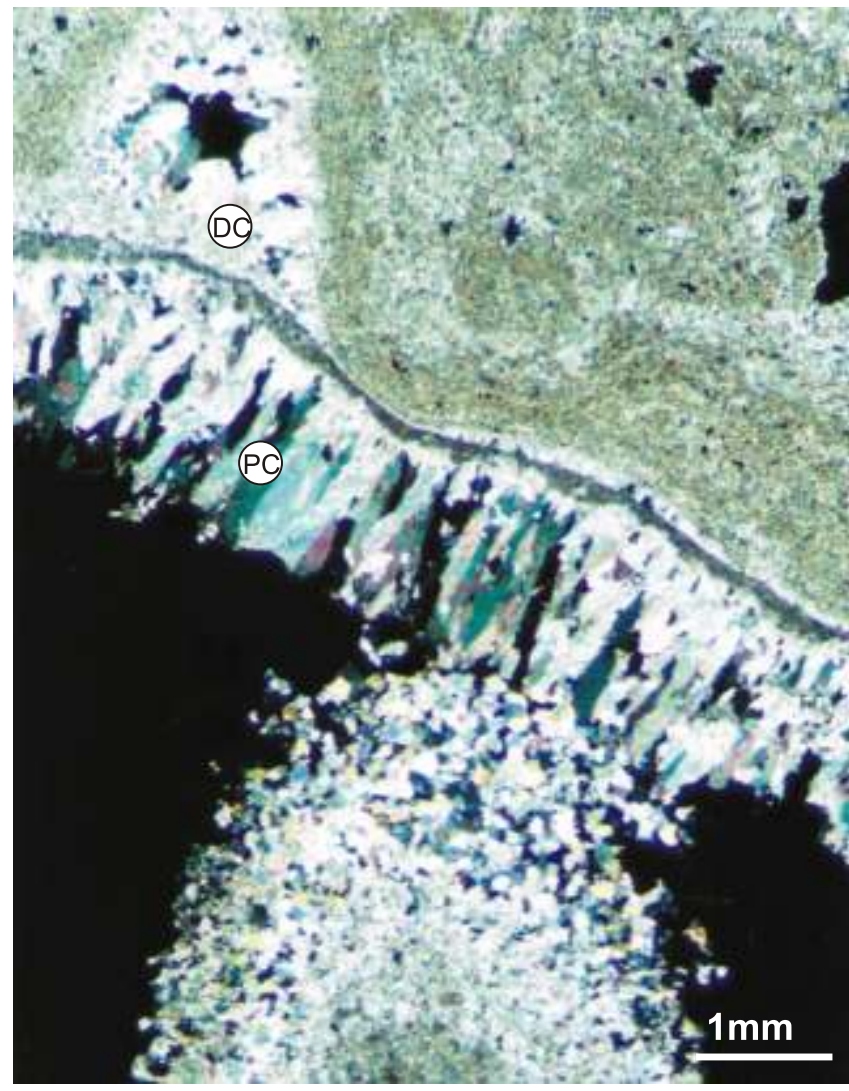

Fig. 10. Palisade (PC) and drusy (DC) calcite within tufa cavities

Crossed polarisers, Dzianiski Stream, outcrop no. 4

Encrustations on moss, crusts on plant remains and porous tufas consist mainly of micrite, typical of microbial cements (Figs. 7L and 10). Crusts, porous soft deposits and massive forms of tufa frequently show laminated fabric with light- and dark-coloured laminae (Fig. 7C, D, L). The laminae are white or white-brown and grey or brown in colour, respectively. Individual laminae range from sub-millimetric to $2 \mathrm{~mm}$ in thickness. In most samples the lamination appears to be heteropachous. In most of the crusts, individual laminae consist of micrite. Thick massive tufas and clastic tufas also show sparite crystals within individual laminae (Fig. 7G). Radiating structures that are concentrically laminated are common in massive tufas (Fig. 7D). Calcite deposition within biofilm layers around clasts of different origin is common in the clastic tufas (Fig. 7G).

Primary fabric-selective porosity produces cemented cavities. Cavities in tufas are frequently infilled by sparite drusy crystals up to $1 \mathrm{~mm}$ in size (Fig. 10). A palisade habit of crystals of such fringe cements has been also observed in association with micrite tufas of different types (Fig. 10).

\section{TUFA DEVELOPMENT}

According to mollusc data (Halicki, 1930; Urbański, 1932; Alexandrowicz, 1984) and stable isotope analysis (Pazdur, 1987; Pazdur et al., 1988) tufas in the Podhale Synclinorium have developed from Late Glacial to Holocene times. Many years of field observations indicate that tufa deposits are continuing to form. Commonly, these deposits may be disinte- grated and destroyed by mechanical (floods) or chemical processes (dissolution), and than later partly or completely rebuilt at the same locality or in its close vicinity.

The tufa accumulations in the Podhale Synclinorium have been influenced by the sedimentary environment as well as by physico-chemical and biological conditions. Calcite precipitation on plants, debris and tree roots - the basic nuclei of crystal growth - produces deposits with irregular fabric and high porosity (Figs. 7B, H and 10) that are characteristic of most initial tufa deposits (Pedley, 2000; Viles and Pentecost, 2008).

Tufa fabric indicates the biotic and/or abiotic origin of calcium carbonate deposits (Fig. 7C, D, L). A laminated texture in micritic tufa may point to seasonal accumulation, locally connected with the growth of algae that form stromatolites similarly to those investigated by Gradziński (2010). These tufas may form in both low and high energy environments.

Well-defined lamination (Fig. 7D) is also characteristic of tufas determined as calcareous sinter (Szulc, 1983 and references therein) indicating abiotic precipitation of calcite. The physico-chemical deposition of calcium carbonate indicates high energy environments and may occur at the outlets of springs and at waterfalls (Szulc 1983; Pentecost and Viles, 1994; Zhang et al., 2001).

The location and composition of clastic tufa deposits indicate high energy environments, probably connected with fall-off processes generated on valley slopes (Vázquez-Urbez et al., 2012). However, the presence of oncoids and admixtures of quartz sand within clastic tufas (Fig. $7 \mathrm{G}$ ) point to flowing water environments, probably small fluvial channels (cf. Vázquez-Urbez et al., 2012). Additionally, alternating microbial and chemical cements may indicate variable conditions during diagenesis of the deposits. All these indicate a complex process of clastic tufa development.

All tufas produce porosity which can be filled by secondary cements during migration of carbonate-rich water. Thus, sub-euhedral, palisade and drusy calcite crystals found in voids and cavities are probably of secondary origin (Figs. $7 \mathrm{G}$ and 10). This process may lead to the formation of massive fabrics in tufas. Depositional processes may be succeeded by diagenesis, which can be of meteoric origin.

It is known that precipitation of freshwater carbonates is induced by: (a) $\mathrm{pH}$ increase of fluids from which calcium carbonate precipitated resulting from e.g., algal growth, (b) factors controlling $\mathrm{CO}_{2}$ degassing of fluids, e.g., assimilation of $\mathrm{CO}_{2}$ in photosynthesis, bacterial and algal activity, increase in fluid temperature or acceleration of diffusion resulting from turbulent flow and/or decrease of partial pressure (Chafetz and Folk, 1984; Gruszczyński and Mastella, 1986; Ford and Pedley, 1996). Freshwater carbonate deposits form in waters with $\mathrm{pH}$ values in the range of 5 to 9 (Szulc, 1983) corresponding to alkaline waters (Pazdro and Kozerski, 1990). The waters associated with tufa occurrences in the Podhale region belong to acratopegae, i.e., they are two-ion waters characterized by $\mathrm{pH}$ values in the range of 7.7 to 8.6 (Kędzierska, 2001; Majewska, 2001; Dziudzik, 2002).

It is significant that the local freshwater carbonates associated with faults are almost exclusively assigned to travertines. They include unique sites such as those in the regions of Levoča and Liptovský Mikuláš (Slovakia) described by Gradziński et al. (2008b). These deposits show a characteristic fabric and indicate an enrichment in $\mathrm{CO}_{2}$ of endogenic origin 
characterized by relatively high values of $\delta^{13} \mathrm{C}$. The lithology and textures of the deposits studied in the Podhale Synclinorium are typical of calcareous tufas. However, few of them form bodies of distinct morphological shape (Fig. 2 - no. $18,40)$ typical of travertines. Moreover, the tufas precipitate mainly near springs and seepages associated with minor and map-scale faults of the major fault zones that reach the Paleogene sedimentary sequence. Additionally, the $\delta^{13} \mathrm{C}$ values of tufas from the Gliczarów region (Fig. 2, no 22) obtained by Pazdur et al. (1988, table 1) indicate partial enrichment in $\mathrm{CO}_{2}$ of deep circulation waters. In this view, the calcareous tufas deposited in the Podhale Synclinorium likely precipitated from mixed waters of deep circulation and meteoric origin (cf. Gradziński, 2010, Lúčky site). The existence of thermal waters in the Podhale Synclinorium is documented in boreholes (Sokołowski, 1991; Chowaniec and Poprawa, 1998; Chowaniec et al., 1999). According to our field observations most of the springs at which tufas precipitate do not freeze in winter. This suggests that tufa development may be related to the tectonics of the Podhale Synclinorium. These data may suggest that thermal waters or waters enriched in $\mathrm{CO}_{2}$, migrating along faults, leached calcium carbonate from the Paleogene sedimentary sequence or the Mesozoic basement and precipitated it on the surface as calcareous tufas.

\section{DISCUSSION AND CONCLUSIONS}

Travertines and tufas are considered to be indicators of tectonic activity and can be used as a tool for identification of a nearby fault trace (Hancock et al., 1999; Brogi et al., 2012), of estimating the age of tectonic activity (Sibson, 1987; Altunel and Hancock, 1993; Hancock et al., 1999; Brogi et al., 2010) or of the permeability of faults and associated brittle structures (Brogi, 2004, 2012) that played a role as conduits of fluids (Cain et al., 1996; Sibson, 1996, 2000).

In this view, tufa occurrences in the Podhale Synclinorium may be regarded as a result of tectonic activity of this region during Quaternary times. It is characteristic that exposures with tufas occur in the vicinity of map-scale as well as mesofault zones (Figs. 2, 4 and 5). Regionally, exposures with tufas occur in several zones, oblique and lateral in relation to the synclinorium axis. The oblique zones are consistent with the Białka and Biały Dunajec fault zones, with a normal component across fault planes. Additionally, the concentration of tufa exposures in the Kacwińska Rzeka and Niedziczanka streams region may indicate the presence of a map-scale fault zone in the eastern part of the synclinorium, similar to the Białka and Biały Dunajec fault zones. The lateral zones occur within the "zone of beds with gentle dips" and in the axial zone of the synclinorium (Fig. 2). The former is related to lateral faults limiting "zone of beds with gentle dips". The latter lateral zone is related to extensional brittle structures in the hinge zone of the synclinorium resulted from buckling of the Podhale Synclinorium during the Neogene (Mastella, 1975). Association of tufas with brittle structures indicates their probable recent and present-day permeability maintained by active tectonics in the Podhale Synclinorium.

The tectonic activity of the Podhale region is documented by thermochronological, geomorphological, instrumental and macroseismic, geodetic as well as satellite image analysis data. The K-Ar, Ar-Ar, and Rb-Sr as well as fission track geochronological data indicating constant uplift of the area (Kováč et al., 1994; Baumgart-Kotarba and Král', 2004; Anczkiewicz et al., 2005; Śmigielski et al., 2012). Data from apatite fission track analyses (Anczkiewicz et al., 2005) indicate that the eastern part of the Podhale Synclinorium underwent a younger and larger uplift in comparison with its western part, dated to between 6 and $10 \mathrm{Ma}$. This is consistent with progressive/gradual offset of the basement along the Biały Dunajec and Białka fault zones (Mastella, 1975; Pomianowski, 1995, 2003). Evidence of Quaternary fault activity is provided by data of geomorphological analyses performed along the Białka River (Baumgart-Kotarba, 1981; Szczęsny, 1987). The present tectonic activity is also consistent with earthquakes of low amplitude recorded in the area of Białka River fault zone, and in the Zakopane region (Guterch and Lewandowska-Marciniak, 2002; Guterch et al., 2005 and references therein). The larger relative uplift of the Zakopane region in comparison to the Nowy Targ region was interpreted from SAR interferometry data (Perski, 2008) that is consistent with previous data of geodynamic measurements obtained by Makowska and Jaroszewski (1987). All the data confirm regional extension during the uplift of the study area, stimulating tufa development.

Acknowledgements. This research was supported by the Institute of Geology (University of Warsaw). We thank M. Gradziński and R. Vojtko for useful and constructive criticism and comments. We are grateful to A. ylińska for linguistic improvement of the manuscript. The Editor T. Peryt is acknowledged for editorial assistance.

\section{REFERENCES}

ALEXANDROWICZ S.W. (1984) - Malacofauna assemblages in the Quaternary deposits of the Polish Carpathians (in Polish with English summary). Biul. Inst. Geol., 346: 187-205.

ALEXANDROWICZ W.P. (1997) - Malacofauna of Quaternary deposits and environmental changes of the Podhale Basin during the Late Vistulian and Holocene (in Polish with English summary). Folia Quatern., 68: 7-121.

ALEXANDROWICZ W.P. (2004) - Molluscan assemblages of Late Glacial and Holocene calcareous tufas in southern Poland. Folia Quatern., 75: 3-309.
ALTUNEL E. and HANCOCK P.L. (1993) - Morphology and structural settings of Quaternary travertines at Pamukkale, Turkey. Geol. J., 28: 335-346.

ANCZKIEWICZ A.A., ZATTIN M. and ŚRODOŃ J. (2005) - Cenozoic uplift of the Tatras and Podhale Basin from the perspective of the apatite fission track analyses. Min. Soc. Pol. Spec. Pap., 25: 261-264.

BAC-MOSZASZWILI M., BURCHART J., GŁAZEK J., IWANOW A., JAROSZEWSKI W., KOTAŃSKI Z., LEFELD J., MASTELLA L., OZIMKOWSKI W., RONIEWICZ P., SKUPIŃSKI A. and 
WESTWALEWICZ-MOGILSKA E. (1979) - Mapa geologiczna Tatr polskich 1:30 000. Wyd. Geol., Warszawa.

BAUMGART-KOTARBA M. (1981) - Tectonic movements in the Eastern Podhale in the light of the analysis of Quaternary terraces of the Białka Tatrzańska valley and the lineaments obtained by means of a satellite (in Polish with English summary). Prz. Geogr., 33: 725-736.

BAUMGART-KOTARBA M. and KRÁL' J. (2002) - Young tectonic uplift of the Tatra Mts. (Fission track data and geomorphological arguments). Geol. Carpath., Spec. Issue, 53.

BIELY A., BEZÁK M., ELEČKO M., KALIČIAK M., KONEČNÝ V., LEXA J., MELLO J., NEMČOK J., POTFAJ M., RAKÚS M., VASS D., VOZÁR J. and VOZÁROVA A. (1996) - Geological map of the Slovak Republic, 1:500 000. Ministerstvo Źivotného Prostredia Slovenskiej Republiky, Geologicka Sluźba Slovenskiej Republiky.

BIRKENMAJER K. (1958a) - Mapa geologiczna Pienińskiego Pasa Skałkowego w skali 1:10 000, ark. Dursztyn. Wyd. Geol., Warszawa.

BIRKENMAJER K. (1958b) - Przewodnik po Pienińskim Pasie Skałkowym. Cz. I. Wyd. Geol., Warszawa.

BIRKENMAJER K. (1964) - Mapa geologiczna Pienińskiego Pasa Skałkowego w skali 1:10 000, ark. Trybsz. Wyd. Geol., Warszawa.

BIRKENMAJER K. (1968) - Mapa geologiczna Pienińskiego Pasa Skałkowego 1:10 000, ark. Bór na Czerwonem (3) i Szaflary (13). Wyd. Geol., Warszawa.

BROGI A. (2004) - Faults linkage, damage rocks and hydrothermal fluid circulation: Tectonic interpretation of the Rapolano Terme travertines (southern Tuscany, Italy) in the context of Northern Apennines Neogene-Quaternary extension. Ecl. Geol. Helv., 97: 307-320.

BROGI A., CAPEZZUOLI E., AQUÉ R., BRANCA M. and VOLTAGGIO M. (2010) - Studying travertines for neotectonics investigations: Middle-Late Pleistocene syn-tectonic travertine deposition at Serre di Rapolano (Northern Apennines, Italy). Internat. J. Earth Sc., 99: 1383-1398.

BROGI A., CAPEZZUOLI E., BURACCHI E. and BRANCA M. (2012) Tectonic control on travertine and calcerous tufa deposition in a low-temperature geothermal system (Sarteano, Central Italy). J. Geol. Soc., 20: 1-16. doi 10.1144/0016-76492011-137.

BUDAY T., CICHA I., HANZLÍKOVÁ E., CHMELÍK F., KORÁB T., KUTHAN M., NEMČOK J., PÍCHA F., ROTH Z., SENEŠ J., SCHEIBNER E., STRÁNÍK Z., VAŠKOVSKÝ I. and ŽEBERA K. (1967) - Regionalni Geologie ČSSR, Díl II, Zapadné Karpaty. Ústr. Úst. Geol., Praha.

CAINE S.J., EVANS J.P. and FORSTER C.B. (1996) - Fault zone architecture and permeability structure. Geology, 24: 1025-1028.

ČABALOVÁ D. (1991) - Travertiny Slovenska. Geologický Průzkum, 1: 4-8.

CHAFETZ H.S. and FOLK R.L. (1984) - Tufas: depositional morphology and the bacterially controlled constituents. J. Sedim. Petrol., 54: 289-316.

CHOQUETTE P.W. and PRAY L.C. (1970) - Geologic nomenclature and classification of porosity in sedimentary carbonates. AAPG Bull., 54: 207-250.

CHOWANIEC J. and POPRAWA D. (1998) - Thermal waters of the Polish part of the Carpathians. Prz. Geol., 46 (8/2): 770-774.

CHOWANIEC J., KĘPIŃSKA B., MAZUREK J., PAWLIKOWSKI M. and POPRAWA D. (1999) - Mineralogical and petrographical investigations of thermal waters' reservoir rocks from Bukowina Tatrzańska PIG/PNiG-1 well (southern Poland) (in Polish with English summary). Prz. Geol., 47 (12): 1096-1100.

DUDZIAK J. (1983) - Stratigraphy of the Podhale Flysch (Palaeogene), Central Carpathians, based on calcareous nannoplankton. I. The Zakopane Formation in Biały Dunajec and Białka valleys (in Polish with English summary). Studia Geol. Pol., 77: 55-81.

DUDZIAK J. (1986) - Stratigraphy of the Podhale Flysch (Palaeogene), Central Carpathians, based on calcareous nannoplankton. III. The Chochołów and Ostrysz formations (in Polish with English summary). Studia Geol. Pol., 88: 157-174.

DZIUDZIK J. (2002) - Tektoniczne uwarunkowania występowania martwic wapiennych w rejonie Dzianisza (Podhale). Praca magisterska. Arch. Inst. Geol. Podst. UW, Warszawa.

FODOR L., CSONTOS L., BADA G., GYÖRFY I. and BENCOVICS L. (1999) - Tertiary tectonic evolution of the Pannonian Basin system and neighbouring orogens: a new synthesis of palaeostress data. Geol. Soc. Spec. Publ., 156: 295-334.
FORD T.D. and PEDLEY H.M. (1996) - A review of tufa and travertine deposits of the world. Earth-Sc. Rev., 41: 117-175.

FUSÁN O. (1963) - Geologicka Mapa ČSSR 1:20 0000, ark. Vysokie Tatry. Ústř. Úst. Geol., Praha.

GARECKA M. (2005) - Calcareous nannoplankton from the Podhale Flysch (Oligocene-Miocene, Inner Carpathians, Poland). Studia Geol. Pol., 124: 353-369.

GEDL P. (2000a) - Biostratigraphy and palaeoenvironment of the Podhale Palaeogene (Inner Carpathians, Poland) in the light of palynological studies. Part I. Studia Geol. Pol., 117: 69-154.

GEDL P. (2000b) - Biostratigraphy and palaeoenvironment of the Podhale Palaeogene (Inner Carpathians, Poland) in the light of palynological studies. Part II. Summary and systematic descriptions. Studia Geol. Pol., 117: 155-303.

GOŁA B J. (1959) - On the geology of the western Podhale Flysch area (in Polish with English summary). Biul. Inst. Geol., 149: 225-237.

GRADZIŃSKI M. (2010) - Factors controlling growth of modern tufa: results of a field experiment. Geol. Soc. Spec. Publ., 336: 143-191.

GRADZIŃSKI M., JACH R. and STWORZEWICZ E. (2001) - Origin of calcite-cemented Holocene slope breccias from the Długa Valley (The Western Tatra Mountains). Ann. Soc. Geol. Pol., 71: 105-113.

GRADZIŃSKI M., BELLA P., CZOP M., DULIŃSKI M., GŁAZEK J., HAVIROVA D., HERCMAN H., HOLÚBEK P., MOTYKA J., MROZIŃSKA T., RAJNOGA P., WRÓBLEWSKI W., STWORZEWICZ E. and WRÓBLEWSKI W. (2008a) - Trawertyny i kras północnej Słowacji. In: Przewodnik sesji terenowych (ed. G. Haczewski). Pierwszy Polski Kongres Geologiczny, 26-28 czerwca 2008, Kraków. Polskie Towarzystwo Geologiczne, Kraków.

GRADZIŃSKI M., DULIŃSKI M., HERCMAN H., STWORZEWICZ E., HOLÚBEK P., RAJNOGA P., WRÓBLEWSKI W. and KOVÁČOVÁ M. (2008b) - Facies and age of travertines from Spiš and Liptov regions (Slovakia) - preliminary results. Slov. Kras, 46: 31-40.

GROSS P. and KÖHLER E. (1980) - Geologia Liptovskiej Kotliny. Geol. Úst. D. Štúra, Bratislava.

GROSS P., KÖHLER E. and SAMUEL O. (1984) - A new lithostratigraphical division of the Inner Carpathian Paleogene (in Slovak with English summary). Geol. Pr., Spr., 81: 103-117.

GRUSZCZYŃSKI M. and MASTELLA L. (1986) - Calcareous tufas in the area of the Mszana Dolna tectonic window (in Polish with English summary). Ann. Soc. Geol. Pol., 56: 117-131.

GUTERCH B. and LEWANDOWSKA-MARCINIAK H. (2002) - Seismicity and seismic hazard in Poland. Folia Quatern., 73: 85-99.

GUTERCH B., LEWANDOWSKA-MARCINIAK H. and NIEWIADOMSKI J. (2005) - Earthquakes recorded in Poland along Pieniny Klippen Belt, Western Carpathians. Acta Geoph. Pol., 53: $28-44$.

HALICKI B. (1930) - Dyluwialne zlodowacenie północnych zboczy Tatr. Spraw. Państw. Inst. Geol., 5: 397-534.

HALICKI B. and LILPOP J. (1932) - Czwartorzędowe trawertyny w Gliczarowie na Podhalu. Pos. Nauk. Państw. Inst. Geol., 27: 6-7.

HANCOCK P.L., CHALMERS R.M.L., ALTUNEL E. and ÇAKIR Z. (1999) - Travitonics: using tufas in active fault studies. J. Struct. Geol., 21: 903-916.

JULIA R. (1983) - Tufas. AAPG Mem., 33: 64-72.

KĘDZIERSKA K. (2001) - Uwarunkowania tektoniczne występowania martwic wapiennych w dorzeczu Białki (Podhale). Praca magisterska. Arch. Inst. Geol. Podst. UW, Warszawa.

KOVANDA J. (1971) - Kvartérní vápence Československa. Sbornik Geologických Věd, Antropozoikum, 7: 5-236.

KOVÁČ M., KRÁL J., MÁRTON E., PLAŠIENKA D. and UHER P. (1994) - Alpine uplift history of the Central Western Carpathians: geochronological, paleomagnetic, sedimentary and structural data. Geol. Carpath., 45: 83-96.

KSIĄ KIEWICZ M. (1972) - Budowa geologiczna Polski, IV. Tektonika, cz. 3. Karpaty. Wyd. Geol., Warszawa.

LEŠKO B. (1958) - Prehl’ad geológie paleogénu južnej časti Levočského pohoria a pril’ahlých Kotlín. Geol. Pr., 12: 14-32.

LOŽEK V. (1961) - Travertines. Pr. Inst. Geol., 34: 81-86.

LOŽEK V. (1964) - Genéza a vek spišských travertinov. Sbornik Východoslovenského Múzea, 5: 7-32.

LUDWINIAK M. (2010) - Multi-stage development of the joint network in the flysch rocks of Western Podhale (Inner Western Carpathians, Poland). Acta Geol. Pol., 60: 283-316. 
MAJEWSKA A. (2001) - Uwarunkowania tektoniczne występowania martwic wapiennych w dorzeczu Białego Dunajca (Podhale). Praca magisterska. Arch. Inst. Geol. Podst. UW, Warszawa.

MAKOWSKA A. and JAROSZEWSKI W. (1987) - On present vertical movements in Tatra Mts. and Podhale (in Polish). Prz. Geol., 35 (10): 506-512.

MAŁECKA D. (1974) - Hydraulic relationships of ground waters of the Middle Podhale region (Carpathians) on the background of its geological structure (in Polish with English summary). Biul. Geol. UW, 15: 87-147.

MAŁECKA D. (1982) - Mapa głównych jednostek geologicznych Podhala i obszarów przyległych. Wyd. Geol., Warszawa.

MARSCHALKO R. (1968) - Facies distribution, paleocurrents and paleotectonics of the Paleogene Flysch of Central West-Carpathians. Geol. Zb. - Geol. Carpath., 19: 69-94.

MASTELLA L. (1975) - Flysch tectonics in the eastern part of the Podhale Basin Carpathians, Poland (in Polish with English summury). Ann. Soc. Geol. Pol., 45: 361-401.

MASTELLA L. (2001) - Tektoniczne uwarunkowania występowania martwic wapiennych we fliszu podhalańskim. Neotektonika Polski. In: Materiały IV Ogólnopolskiej Konferencji Komisji Neotektoniki Komitetu Badań Czwartorzędu PAN (eds. W. Zuchiewicz): 76-79. September 3-4, 2001, Kraków.

MASTELLA L. and MIZERSKI W. (1977) - Some remarks on geological structure of south-western Podhale (in Polish with English summary). Prz. Geol., 25 (10): 494-499.

MASTELLA L., KONON A. and MARDAL T. (1996) - Tectonics of the Podhale Flysch, Białka River Valley, southern Poland (in Polish). Prz. Geol., 44 (12): 1189-1194.

MASTELLA L., LUDWINIAK M. and KLIMKIEWICZ D. (2012) - Geology of the Biały Dunajec Valley (Podhale region, S Poland) (in Polish with English summary). Prz. Geol., 60 (9): 496-505.

PAZDRO Z and KOZERSKI B (1990) - Hydrogeologia ogólna. Wyd. Geol., Warszawa.

PAZDUR A. (1987) - Isotopic composition of carbon and oxygen in Holocene calcareous tufa sediments (in Polish with English summary). Zesz. Nauk. P.Śl., 1019: 14-75.

PAZDUR A., PAZDUR M.F. and SZULC J. (1988) - Radiocarbon dating of Holocene calcareous tufa in southern Poland. Radiocarbon, 30: $133-151$.

PEDLEY H.M. (1990) - Classification and environmental models of cool freshwater tufas. Sedim. Geol., 68: 143-154.

PADLEY H.M. (2000) - Ambient temperature freshwater microbial tufas. In: Microbial sediments (eds. R.E. Riding and S.M. Awramiks): 179-186. Springer-Verlag, Berlin.

PENTECOST A. (1995) - The Quaternary travertine deposits of Europe and Asia Minor. Quatern. Sc. Rev., 14: 1005-1028.

PENTECOST A. (2005) - Travertines. Springer-Verlag, Berlin and Heidelberg.

PENTECOST A. and VILES A. (1994) - A review and reassessment of travertine classification. Geogr. Fis. Quatern., 48: 305-314.

PERSKI Z. (2008) - Recent tectonic activity of the Tatra Mts and Podhale (Poland) studied by InSAR and PSInSAR (in Polish with English summary). Prz. Geol., 56 (12): 1082-1086.

POMIANOWSKI P. (1995) - Tectonics of the Orava-Nowy Targ Basin results of the combined analysis of the gravity and geoelectrical data (in Polish with English summary). Prz. Geol., 51: 498-506.

POMIANOWSKI P. (2003) - Structure of the Orava Basin in the light of selected geophysical data (in Polish with English summary). Ann. Soc. Geol. Pol., 64: 67-80.

RABOWSKI E. (1930) - Dyluwialne martwice wapienne w Tatrach. Pos. Nauk. Państw. Inst. Geol., 27: 45.

RUTKOWSKI J. (1991) - Holocene deposits in the Racławka River Valley (in Polish with English summary). Zesz. Nauk. AGH, Geologia, 17: 173-191.

SIBSON R.H. (1996) - Structural permeability on fluid-driven fault-fractured meshes. J. Struct. Geol., 18: 1031-1042.

SIBSON R.H. (1987) - Earthquake rupturing as a mineralising agent in hydrothermal sysytems. Geology, 15: 704-710.
SIBSON R.H. (2000) - Fluid involvement in normal faulting. J. Geodynam., 29: 469-499.

SMIEJA and SMIEJA-KRÓL (2007) - Springs with active calcium carbonate precipitation in the Polish part of the Tatra Mountains. In: Karst and Cryokarst (ed. A. Tyc and K. Stefaniak): 219-226. Univ. Silesia, Faculty of Earth Sciences, Univ. Wrocław, Zoological Institute, Sosnowiec, Wrocław.

SOKOŁOWSKI J. (1991) - Dokumentacja obiektów geotermalnych. Materiały konferencyjne: Problemy geotermii, środowiska przyrodniczego i kulturowego Tatr, Podhala, Orawy, Spisza i Gorców, 9 października 1991, Zakopane: 7-50.

SOKOŁOWSKI S. (1959) - Geological map of the Nummulitic Eocene region (northern margin of the Polish Tatra). Preliminary report (in Polish with English summary). Biul. Inst. Geol., 149: 197-213.

STĘPCZAK P. (2011) - Analiza spękań ciosowych we fliszu podhalańskim wzdłu potoku Kacwińska Rzeka (Podhale). Praca magisterska. Arch. Inst. Geol. Podst. UW, Warszawa.

SZCZESNY R. (1987) - Geologic interpretation of lineament from Podhale (in Polish with English summary). Biul. Geol. UW, 31: 401-410.

SZULC J. (1983) - Origin and classification of tufa deposits (in Polish with English summary). Prz. Geol., 31 (4): 231-237.

SZULC J. (1986) - Holocene tufa deposits of the Cracow Upland. IAS 7th European Meeting. Excursion Guide-Book: 185-189. ING UJ, Kraków.

ŚMIGIELSKI M., STUART F., PERSANO C., KRZYWIEC P., SINCLAIR H., ALEKSANDROWSKI P. and PISANIEC K. (2012) Subsequent exhumation, burial and exhumation of the Tatra Mountains constrained by the low temperature thermochronology. Miner. Slov., 44: 105.

UHLIG J. (1897) - Atlas geologiczny Galicji, 1:75 000, z. 24, Zakopane, Nowy Targ. Wiedeń.

UHLIG J. (1903) - Bau und Bild der Karpathen. Wien.

URBAŃSKI J. (1932) - Beitrag zur Kenntnis der Mollusken der interglazialen Tufa von Gliczarów bei Zakopane. Rocz. Pol. Tow. Geol., 8: 205-209.

VÁZQUEZ-URBEZ M., ARENAS C. and PARDO G. (2012) - A sedimentary facies model for stepped, fluvial tufa system in the Iberian Range (Spain): the Quaternary Piedra and Mesa Valleys. Sedimentology, 59: 502-526.

VILES H.A. and PENTECOST A. (2008) - Tufa and Tufa. In: Geochemical Sediments and Landscapes (eds. D.J. Nash and S.J. McLaren): 173-199. Blackwell, Oxford.

VOJTKO R., TOKÁROVÁ E., SLIVA L. and PEŠKOVÁ I. (2010) - Cenozoic palaeostress field reconstruction and revised tectonic history in the northern part of the Central Western Carpathians (the Spišská Magura and Tatra Mountains). Geol. Carpath., 61: 211-225.

WATYCHA L. (1959) - Remarks on geology of the Podhale Flysch in the eastern part of Podhale (in Polish). Prz. Geol., 7 (8): 350-356.

WATYCHA L. (1968) - Preliminary estimations of conditions and possibilities of formation of oil deposits in the eastern part of the Podhale Flysch (in Polish with English summary). Kwart. Geol., 12 (4): 898-915.

WATYCHA L. (1974) - Szczegółowa mapa geologiczna Polski w skali 1:50 000, ark. Nowy Targ. Wyd. Geol., Warszawa.

WATYCHA L. (1976) - Szczegółowa mapa geologiczna Polski w skali 1:50 000, ark. Czarny Dunajec. Wyd. Geol., Warszawa.

WATYCHA L. (1977) - Objaśnienia do Szczegółowej mapy geologicznej Polski w skali 1:50 000, ark. Czarny Dunajec. Wyd. Geol., Warszawa.

ZHANG D.D., ZHANG Y., ZHU A. and CHENG X. (2001) - Physical mechanism of river waterfall tufa (travertines) formation. J. Sedim. Res., A71: 205-216.

ZÝKA V. and VTĚLENSKÝ J. (1960) - Geochemie slovenskych travertinu. Geol. Pr., 17: 149-195.

YTKO K., ZAJĄC R., GUCIK S., RYŁKO W., OSZCZYPKO N., GARLICKA I., NEMČOK J., ELIAŠ M., MENČIK E. and STRÁNIK Z. (1989) - Map of the tectonic elements of the Western Outer Carpathians and their foreland. In: Geological atlas of the Western Outer Carpathians and their foreland (eds. D. Poprawa and J. Nemčok). Wyd. Geol., Warszawa. 